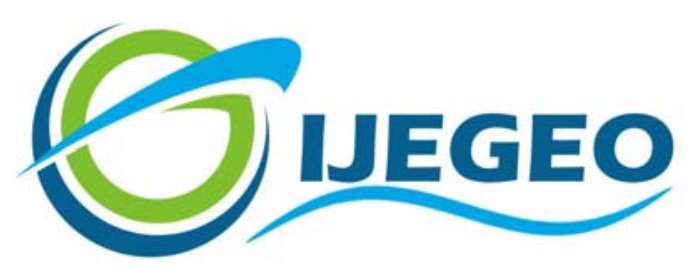

International Journal of Environment and Geoinformatics (IJEGEO) is an international, multidisciplinary, peer reviewed and certified open access journal.

\title{
Soil Moisture Mapping Using Sentinel-1A Synthetic Aperture Radar Data
}

\author{
Aliihsan Şekertekin, Aycan Murat Marangoz and Saygın Abdikan \\ Editors \\ Prof. Dr. Cem Gazioğlu, Prof. Dr. Dursun Zafer Şeker, Prof. Dr. Ayşegül Tanık, \\ Prof. Dr. Şinasi Kaya, Assist. Prof. Dr. Volkan Demir
}

\section{Scientific Committee (2018)}

Dr. Abdullah Aksu, Prof. Dr. Bedri Alpar, Prof. Dr. Gülşen Altuğ, Prof. Dr. Lale Balas, Prof. Dr. Can Balas, Prof. Dr. Levent Bat, Prof. Dr. Bülent Bayram, Prof. Dr. Nuray Çağlar, Prof. Dr. Jadunandan Dash, Prof. Dr. A. Evren Erginal, Dr. Dieter Fritsch, Dr. Amin Gharehbaghi, Assoc. Prof. Dr. Tolga Görüm, Prof. Dr. Melike Gürel, Dr. Hakan Kaya, Prof. Dr. Fatmagül Kılıç, Assoc. Prof. Dr. Maged Marghany, Prof. Dr. Nebiye Musaoğlu, Prof. Dr. Masafumi Nakagawa, Prof. Dr. Haluk Özener, Prof. Dr. Erol Sarı, Prof. Dr. Elif Sertel, Prof. Dr. Nüket Sivri, Assoc. Prof. Dr. Füsun Balık Şanlı, Prof. Dr. Uğur Şanlı, Assoc. Prof. Dr. Hasan Özdemir, Prof. Dr. Taşkın Kavzoğlu, Msc. Mustafa Üstüner, Assoc. Prof. Dr. Oral Yağcı, Prof. Dr. Seyfettin Taş, Assoc. Prof. Dr. Ömer Suat Taşkın, Assoc. Prof. Dr. İ. Noyan Yılmaz, Dr. Baki Yokeş, Dr. Sibel Zeki 


\title{
Soil Moisture Mapping Using Sentinel-1A Synthetic Aperture Radar Data
}

\author{
Aliihsan Şekertekin ${ }^{1, *}$, Aycan Murat Marangoz ${ }^{2}$, Saygın Abdikan $^{2}$ \\ ${ }^{1}$ Cukurova University, Ceyhan Engineering Faculty, Department of Geomatics Engineering, 01950, Ceyhan, Adana, TR \\ ${ }^{2}$ Bulent Ecevit University, Engineering Faculty, Department of Geomatics Engineering, 67100, Zonguldak, TR

\begin{abstract}
The aim of this study is to estimate and map soil moisture distribution using C-band Synthetic Aperture Radar (SAR) data. Sentinel-1A is a new generation C-band SAR satellite, and in this study Sentinel-1A data acquired on 24 April 2016 were used to retrieve soil moisture map. An agricultural region in Bergama, a district of İzmir city, was chosen as the study area. In-situ soil moisture measurements were carried out in 20 test fields simultaneously with SAR data acquisition. The effects of soil moisture and local incidence angle on backscattering coefficient were analyzed, and then a multiple regression analysis was performed to generate an empirical model. The proposed model was evaluated using statistical metrics namely coefficient of determination $\left(\mathrm{R}^{2}\right)$ and Root Mean Square Error (RMSE), and the results were 0.84 and $2.46 \%$, respectively. The obtained results showed that Sentinel-1A SAR data presented satisfying outcomes to estimate and map soil moisture content.
\end{abstract}

Keywords: Microwave Remote Sensing, Soil Moisture Mapping, Synthetic Aperture Radar (SAR), Sentinel-1

\section{Introduction}

Soil moisture is an important variable for many environmental phenomena including meteorological, agricultural and hydrological applications (Ahmad, Zhang, and Nichols, 2011; Lakshmi, 2013; Verhoest et al., 2008). Furthermore, soil moisture content can be considered as an indicator of natural disasters such as flooding, droughts and for environmental changes, such as dust storms and erosions (Ahmad et al., 2011; Canada Center for Remote Sensing, 1976). Soil moisture has a dynamic structure and thus, monitoring spatial and temporal variations in soil moisture is of great importance for ecological balance. Considering classical methods, measuring accurate in situ soil moisture is sometimes expensive and mostly time-consuming. In addition, it requires repetitive measurements to determine temporal changes.

Estimation of soil moisture from space is one of the most important topics in remote sensing society. There are many studies on estimating soil moisture using both passive (Heilman,
Kanemasu, Bagley, and Rasmussen, 1977; Sadeghi, Babaeian, Tuller, and Jones, 2017; Shih and Jordan, 1992) and active remote sensing satellites. Because of the remarkable penetrating capabilities of radar signal into the surface, active microwave remote sensing systems have been recently preferred in soil moisture studies. Synthetic Aperture Radar (SAR) sensor is the most common active microwave remote sensing system for Earth observation. Many studies have been presented to retrieve soil moisture content from X-band (Aubert et al., 2011; Baghdadi et al., 2011; Baghdadi, Aubert, and Zribi, 2012; Kseneman, Gleich, and Potočnik, 2012; Zribi et al., 2012), C-band (Jacome et al., 2013; Şeker et al., 2013; Lievens and Verhoest, 2012; Moran et al., 2012; Srivastava, Patel, Sharma, and Navalgund, 2009; Kurucu et al., 2009) and Lband (Balenzano et al., 2013; Paloscia, Pettinato, and Santi, 2012; Şekertekin, 2018) SAR data.

Considering bare soil, the backscattered SAR signal is affected strongly from soil moisture and surface roughness (Ulaby, Moore, and 
Fung, 1986; Zribi et al., 2007). Many models have been developed to understand the interaction between SAR signal and the surface. For bare soils, different theoretical and empirical approaches have been developed (Dubois, van Zyl, and Engman, 1995; Oh, Sarabandi, and Ulaby, 1992; Zribi and Dechambre, 2003), and many approaches assumed that there is a linear behavior between surface soil moisture and SAR backscattering coefficient (sigma-nought: $\sigma^{0}$ ) (Esetlili and Kurucu, 2016; Gao, Zribi, Escorihuela, and Baghdadi, 2017; Şanlı et al., 2016; Zribi, Baghdadi, Holah, and Fafin, 2005). The aim of this study is to map soil moisture distribution using the data of new generation C-band SAR satellite Sentinel-1A.

\section{Study Area and Material}

An agricultural region in Bakırçay river basin in Bergama was chosen as the study area (Figure 1). Bergama is one of the districts of
İzmir province in Turkey. The study area is located on the northern side of Izmir city, and it is an important agricultural production center in İzmir. There are different kinds of agricultural products in the region including cotton, okra, corn, grape, tobacco and olive.

In the study area, twenty test fields were determined for in-situ soil moisture measurements, and there was no vegetation cover in the test fields. In addition, the surface roughness, which is another important variable affecting backscattering coefficient, was ignored because it was not so high for the test sites. The field work was conducted two days before the SAR data acquisition. Since there was no irrigation and rain in the area, it was appropriate to use these measurements to analyze the relationship between surface soil moisture and backscattering coefficient. Soil moisture measurements were carried out using metal soil moisture tins with $5 \mathrm{~cm}$ height as seen in Figure 2.

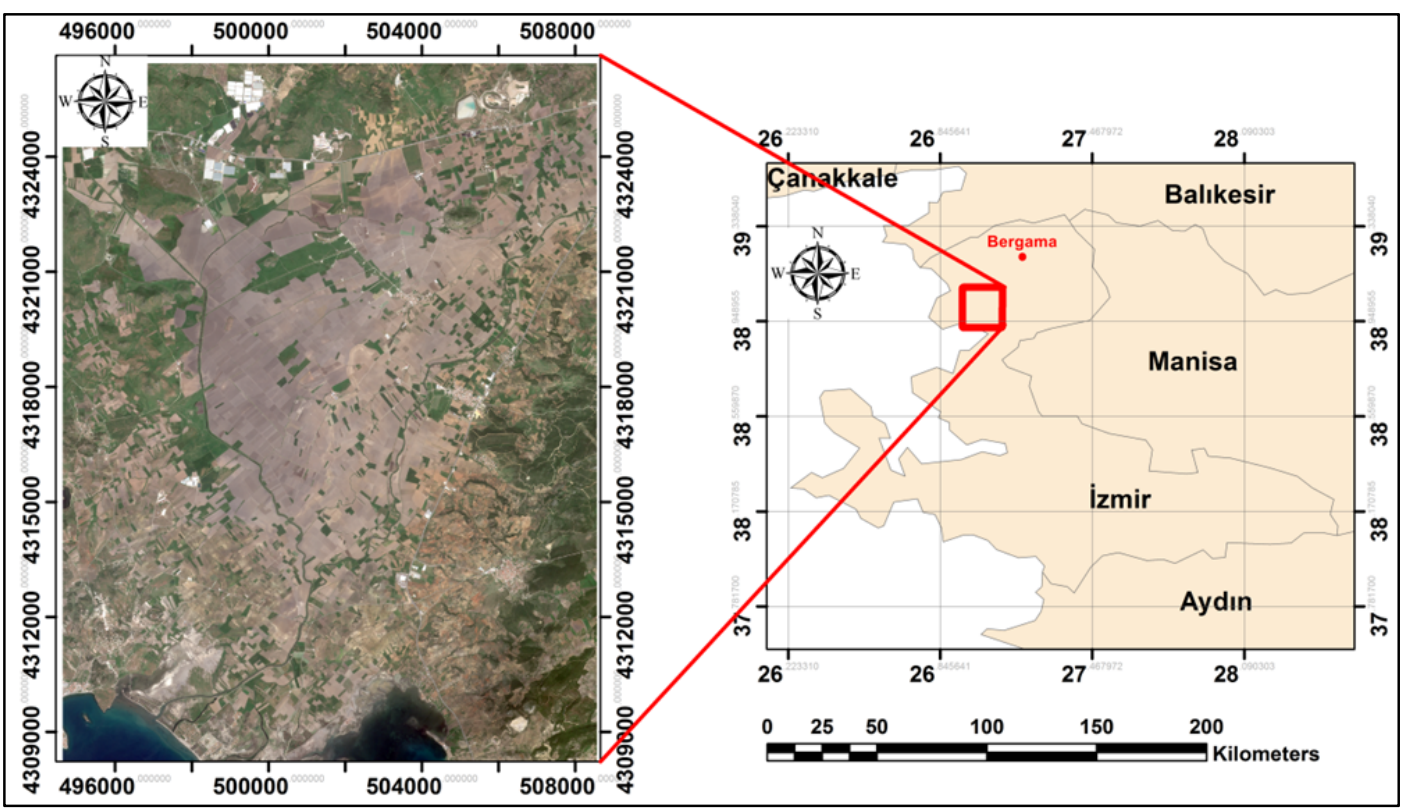

Fig 1. Bergama study area, including a general overview (right) and RGB image of Sentinel-2 satellite acquired on 18 April 2016 (left). 


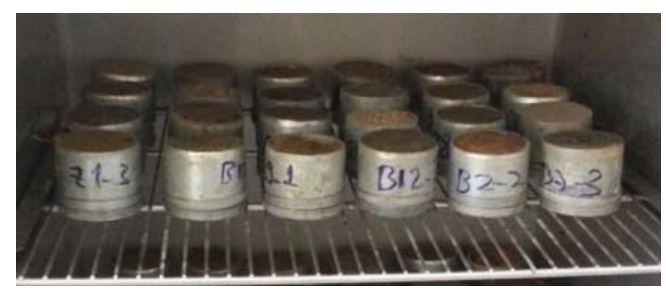

Fig 2. The metal tins used to obtain soil samples for moisture content.

Sentinel-1A satellite data were utilized as material to map soil moisture distribution. Sentinel-1 is the European Radar Observatory representing the first new space component of the Global Monitoring for Environment and Security (GMES) satellite family that was designed and developed by European Space Agency (ESA) and funded by the EC (European Commission). Sentinel-1 is composed of a constellation of two satellites, namely Sentinel-1A and Sentinel-1B. The mission provides an independent operational capability for continuous radar mapping of the Earth with enhanced revisit frequency, coverage, timeliness and reliability for operational services and applications requiring long time series (Copernicus, 2018). Sentinel-1 satellite provides $\mathrm{C}$-band images in both singular and dual polarization within 12 days of repeat cycle. The data is free of charge for all users which makes it more attractive for new challenging applications and opportunities (Nagler, Rott, Hetzenecker, Wuite, and Potin, 2015).

Table 1. The specifications of Sentinel-1A data used in the study.

\begin{tabular}{|l|l|}
\hline \multicolumn{1}{|c|}{ Specifications } & \multicolumn{1}{c|}{ Sentinel-1A data } \\
\hline Acquisition time & 24 April 2016 \\
\hline Acquisition orbit & Descending \\
\hline Imaging Mode & $\mathrm{IW}$ \\
\hline Imaging frequency & $\mathrm{C}$-band $(5.4 \mathrm{GHz})$ \\
\hline Polarization & VV-VH \\
\hline Data product & Level-1 SLC \\
\hline Resolution mode & $10 \mathrm{~m}$ \\
\hline
\end{tabular}

It can acquire images in three acquisition modes as Stripmap (SM), Interferometric Wide Swath (IW), Extra Wide Swath (EW) and Wave (WV) with different processing levels. In this study, Level-1 Single Look Complex (SLC) product of Sentinel-1A was utilized. Sentinel-1A image was acquired on 24
April 2016, with the acquisition mode of IW mode. The specifications of the data are given in Table 1

\section{Methodology}

In this section, the method, used for soil moisture determination, was introduced. Then, image processing steps and analyzing methods were presented.

\section{Soil Moisture Determination}

Current methods of determining soil moisture are generally considered in two groups, namely direct and indirect methods. In direct methods, the soil moisture is calculated regarding the difference between the weights of the soil sample before and after drying. In indirect methods, measurements of other variables affecting the content of soil moisture are determined by a sensor and soil moisture content can be calculated using these variables (Evett and Parkin, 2005). Direct method is unique and it is called as gravimetric method. All other methods are indirect methods due to the dependency of a device to estimate soil moisture.

In this study, the soil samples were collected from 20 test fields having no vegetation cover. Gravimetric analysis of the soil samples provides accurate soil moisture data (B. E. Myhre and S. F. Shih, 1990). Thus, gravimetric soil moisture determination method was applied (Schmugge, Jackson, and McKim, 1980). In the gravimetric method, the soil samples collected from the field are firstly weighed, and then they are placed in the oven and dried at $105^{\circ} \mathrm{C}$ for 24 hours. Following the drying process, the samples are weighed again to obtain dry weights, and soil moisture is estimated using the equation (1).

Soil Moisture $=\left(\frac{\mathrm{M}_{1}-\mathrm{M}_{2}}{\mathrm{M}_{2}-\mathrm{M}_{0}}\right) \times 100$

Where M1 is weight of wet soil with tare, M2 is weight of dry soil with tare, and M0 is weight of the tare. 


\section{Sentinel-1A Image Processing}

Sentinel-1A image was acquired in descending orbit direction and IW mode as Level-1 SLC product which contains phase and amplitude information. In order to use SLC product in environmental studies, it is required to convert SLC product to Ground Range Detected (GRD) product. For this conversion, ESA announced some steps to be performed with open source tools of Sentinel Application Platform (SNAP) software. The steps include radiometric calibration, thermal noise removal, TOPSAR deburst and merge, multi-look, topographic correction using SRTM 1Sec HGT data. While applying topographic correction, local incidence angle map was also generated by using SRTM data. In addition, the final resolution of Sentinel1A GRD image was $10 \mathrm{~m}$.

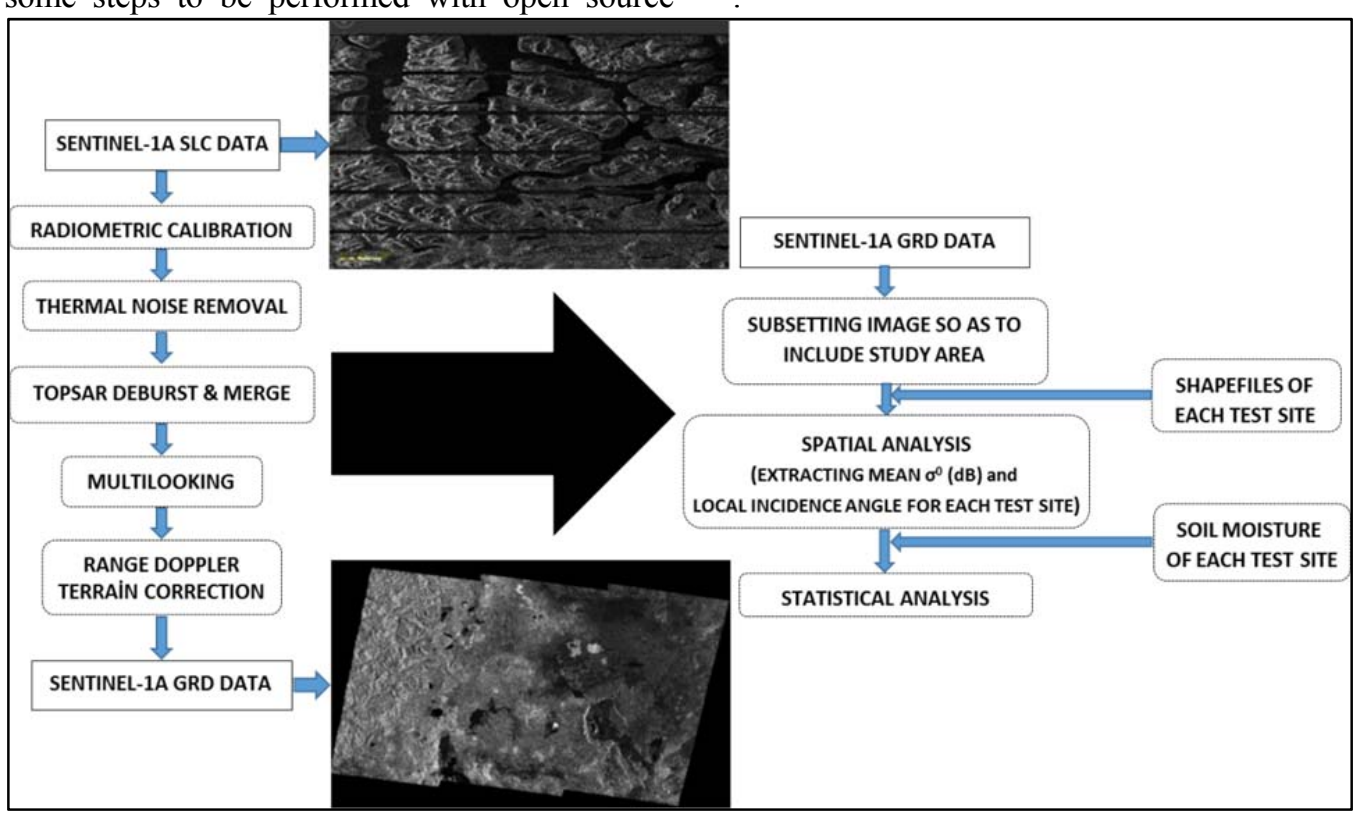

Fig 2. The workflow scheme of the methodology.

The workflow of the methodology is presented in Figure 3. After generating Sentinel-1A GRD data from SLC product, the image was subsetted so as to specifically illustrate the study area. Then, the shape files were created for each test site, and mean $\sigma^{0}(\mathrm{~dB})$ and local incidence angle values of each test site were extracted using the shape files. Afterwards, the linear regression analysis was conducted to generate an empirical model

Empirical models present information about the effects of variables such as soil moisture, local incidence angle, surface roughness and dielectric constant on backscattering coefficient by the help of regression analysis. The simplest empirical model is given in equation (2). Soil moisture content can be obtained by inverting this model.

$\sigma^{0}=\mathrm{a} \cdot \mathrm{m}_{\mathrm{s}}+\mathrm{b}$
Where $\mathrm{a}$ and $\mathrm{b}$ are coefficients, and $\mathrm{m}_{\mathrm{s}}$ refers to surface soil moisture. Many researchers established empirical relationships to estimate soil moisture, and these models revealed that there is a fundamental relation between soil moisture and backscattering coefficient (Sekertekin, Marangoz, Abdikan, and Esetlili, 2016; Weimann, Von Schonermark, Schumann, Jorn, and Gunther, 1998; Zribi et al., 2005).

In this study, an empirical model, which was based on the influence of soil moisture and local incidence angle on backscattering coefficient, was developed. We considered backscattering coefficient and local incidence angle as a function of soil moisture as seen in equation (3) and (4).

$\mathrm{m}_{\mathrm{s}}=\mathrm{f}\left(\sigma_{\mathrm{TR}}^{0}, \theta_{\mathrm{i}}\right)$

$\mathrm{m}_{\mathrm{s}}=\mathrm{a}+\mathrm{b} \cdot \sigma_{\mathrm{TR}}^{0}+\mathrm{c} \cdot \theta_{\mathrm{i}}$ 
Where $\sigma_{\mathrm{TR}}^{0}$ is backscattering coefficient (TR: Transmitted-Received), $\theta_{\mathrm{i}}$ is the local incidence angle. In this multiple regression analysis, $m_{\mathrm{s}}$ is considered as dependent variable, whereas $\sigma_{\mathrm{TR}}^{0}$ and $\theta_{\mathrm{i}}$ are independent variables.

\section{Validation of Soil Moisture}

In order to evaluate the proposed model, statistical metrics namely coefficient of determination $\left(\mathrm{R}^{2}\right)$ and Root Mean Square Error (RMSE) were utilized. The equations of these two statistical metrics are presented in Equation (5) and (6).

$$
\mathrm{R}^{2}=\left[\frac{\sum\left(\mathrm{M}_{\text {in-situ }}-\overline{\mathrm{M}_{\text {in-situ }}}\right)\left(\mathrm{M}_{\text {Model }}-\overline{\mathrm{M}_{\text {Model }}}\right)}{\sqrt{\sum\left(\mathrm{M}_{\text {in-situ }}-\overline{\mathrm{M}_{\text {in-situ }}}\right)^{2}} \sqrt{\sum\left(\mathrm{M}_{\text {Model }}-\overline{\mathrm{M}_{\text {Model }}}\right)^{2}}}\right]^{2}
$$

$\mathrm{RMSE}=\sqrt{\frac{\sum\left[\mathrm{M}_{\mathrm{in}-\text { situ }}-\mathrm{M}_{\text {Model }}\right]^{2}}{\mathrm{n}}}$

Where $M_{\text {in-situ }}$ and $M_{\text {Model }}$ are in-situ soil moisture and estimated soil moisture from model, respectively, and $\overline{\mathrm{M}_{\text {in-situ }}}$ and $\overline{\mathrm{M}_{\text {Model }}}$ are mean in-situ soil moisture and mean estimated soil moisture from model, respectively. $\mathrm{n}$ represents the count of test fields.

\section{Results}

Backscatter image in $\mathrm{VV}$ polarization is generated using the steps aforementioned above and illustrated in Figure 4. In this section, the influences of $\mathrm{m}_{\mathrm{s}}$ and $\theta_{\mathrm{i}}$ on $\sigma^{0}$ were investigated. The relationship between $\sigma^{0}$ and $\mathrm{m}_{\mathrm{s}}$, and $\theta_{\mathrm{i}}$ were presented in Figure 5 and Figure 6, respectively, using linear regression analysis. All polarizations of Sentinel-1A data (VV, VH) were analyzed in order to determine which polarization is more sensitive to soil moisture content.

As it was presented in Figure 5, VV polarization was more sensitive to soil moisture content and the coefficient of determination $\left(\mathrm{R}^{2}\right)$ values for $\mathrm{VV}$ and $\mathrm{VH}$ polarizations were determined as 0.74 and 0.40 , respectively. Considering the relation between $\sigma^{0}$ and $\theta_{\mathrm{i}}$, it was observed from Figure 6 that local incidence angle did not have high correlation with backscattering coefficient.

In this study, a multiple regression analysis was carried out to estimate and map soil moisture content. Therefore, $\mathrm{m}_{\mathrm{s}}$ was considered as dependent variable, and $\sigma_{\mathrm{VV}}^{0}$ and $\theta_{\mathrm{i}}$ were chosen as independent variables. While 13 test sites were utilized in order to generate model, 7 test sites were used for the accuracy assessment. As a result of multiple regression analysis, mathematical model for soil moisture estimation from $\sigma_{\mathrm{VV}}^{0}$ and $\theta_{\mathrm{i}}$ was generated as seen in equation (7). The accuracy assessment was conducted using 7 test sites, and the statistical metrics, namely $\mathrm{R}^{2}$ and RMSE, were determined as 0.84 and $2.46 \%$, respectively (Figure 7). As it was clear from Figure 7, backscattering coefficient and local incidence angle could help determining soil moisture estimation.

$\mathrm{m}_{\mathrm{s}}=57.949+1.447 \cdot \sigma_{\mathrm{VV}}^{0}-0.521 \cdot \theta_{\mathrm{i}}$

(Eq. 7)

In order to map soil moisture distribution, the proposed model was implemented to the images using band math operation in SNAP software developed by ESA. Soil moisture map was illustrated in Figure 8, and the soil moisture content of the study area ranged between 0 and $35 \%$. In soil moisture map, vegetated areas and water body were masked using Normalized Difference Vegetation Index (NDVI) image generated from Sentinel-2 optical data acquired on 18 April 2016.

\section{Conclusions}

In this study, an empirical model was developed to map soil moisture content using C-band SAR Satellite Sentinel-1A data. In order to develop model, multiple regression analysis was conducted, and soil moisture was considered as a dependent variable whereas backscattering coefficient and local incidence angle were chosen as independent variables. Validation results showed that the proposed empirical model estimated soil moisture content with RMSE $2.46 \%$, which was very close to in-situ moisture content. 


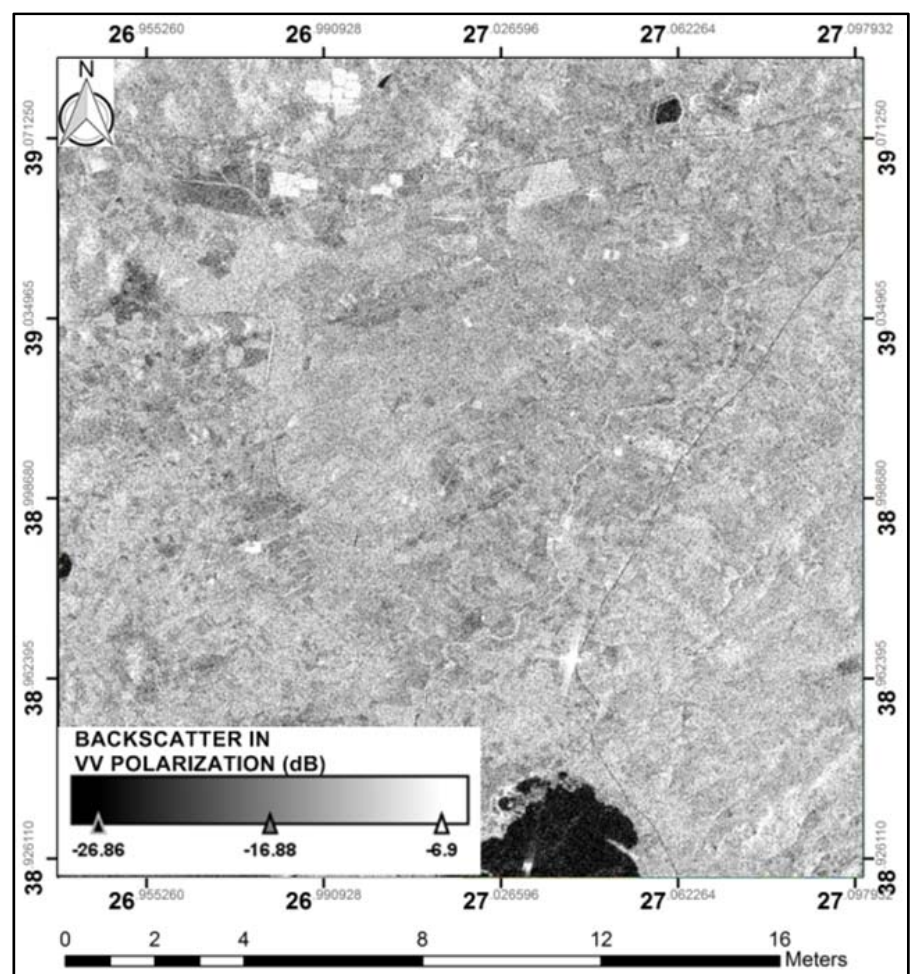

Fig 4. $\sigma^{0}$ image of the study area in $\mathrm{VV}$ polarization.

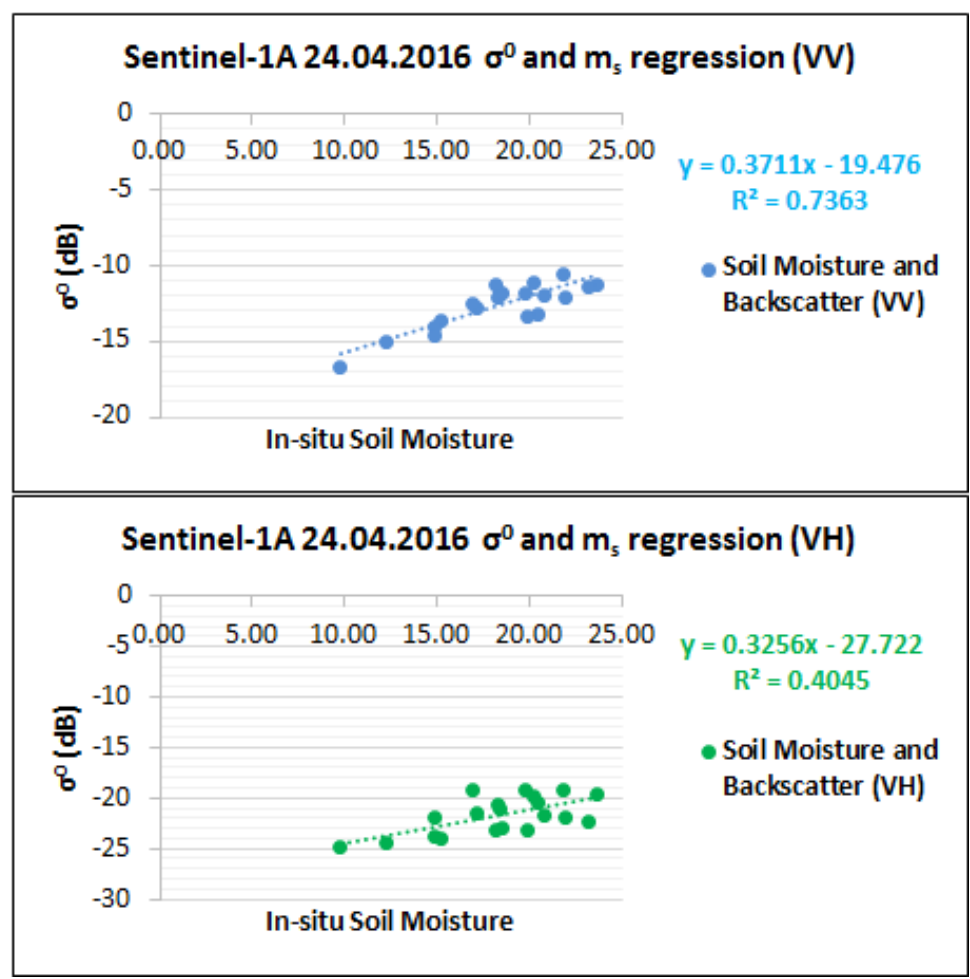

Fig 5. The linear regression analysis between $\sigma^{0}$ and $\mathrm{m}_{\mathrm{s}}$ for all polarizations. 


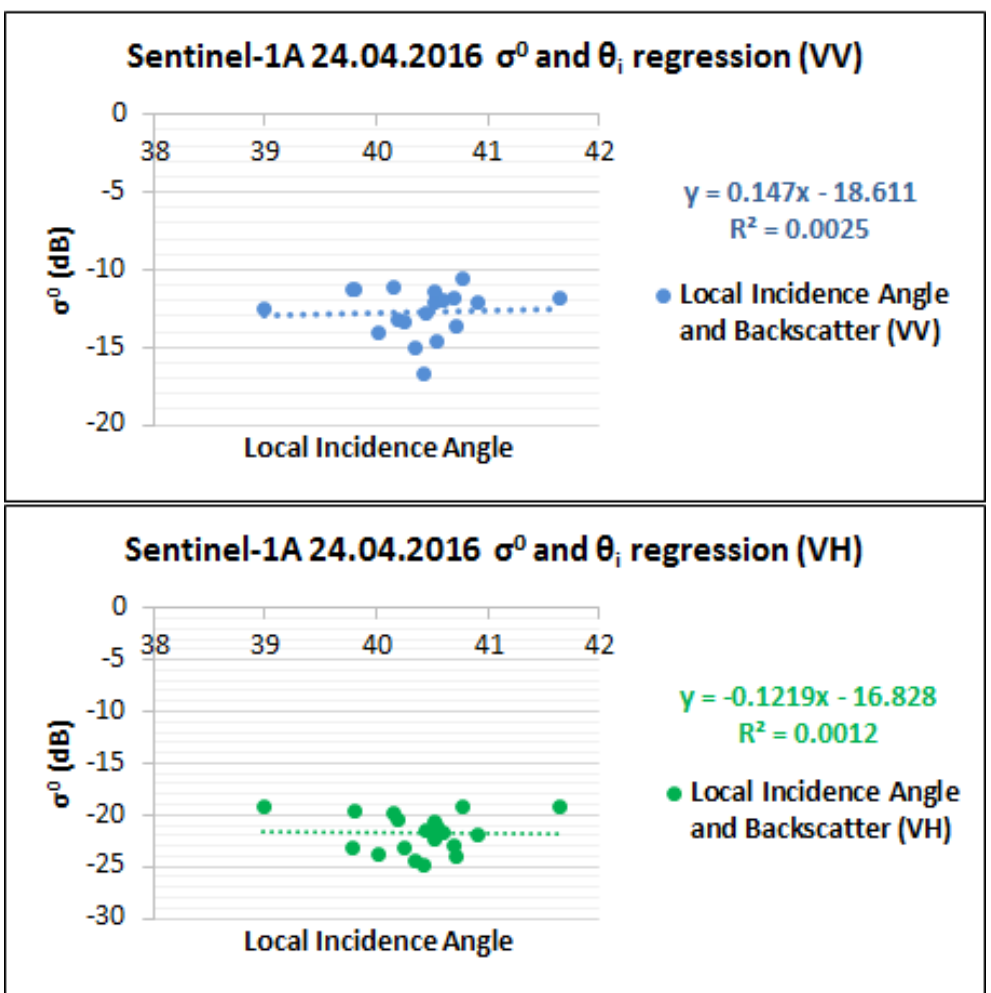

Fig 6 . The linear regression analysis between $\sigma^{0}$ and $\theta_{\mathrm{i}}$ for all polarizations.

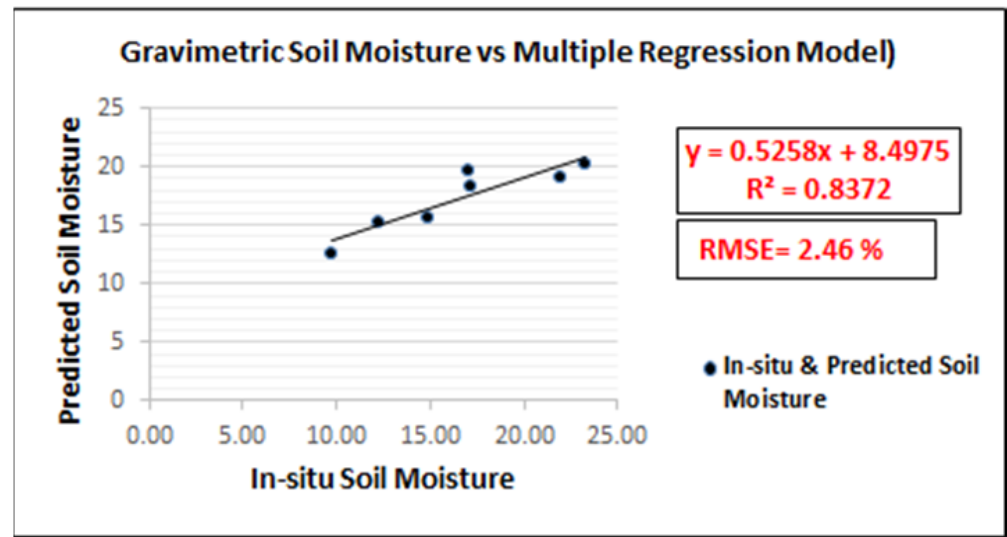

Fig 7. The accuracy assessment results of the proposed model. 


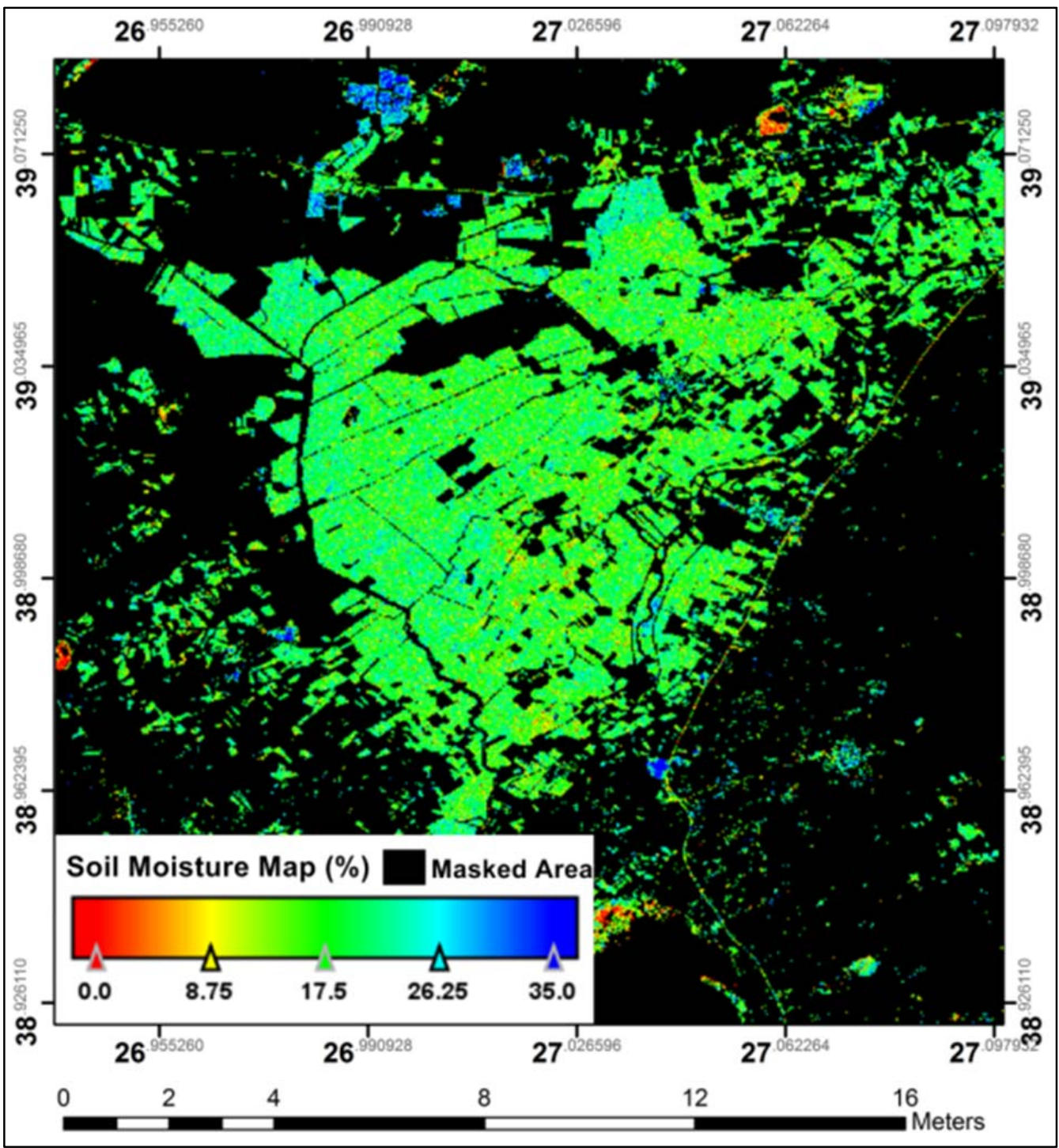

Fig 8 . The soil moisture map of the study area.

Additionally, the correlations of local incidence angle and soil moisture with backscattering coefficient were analyzed, and it was observed that soil moisture was highly correlated with backscattering coefficient while local incidence angle was not.

Soil moisture is an important factor for many disciplines, and it is hard to determine soil moisture on a large scale. Remote sensing is an effective science to detect and monitor Earth resources, and estimation of soil moisture distribution has been one of the most outstanding topics in Remote Sensing Society.

The obtained results of this study revealed that new generation C-band SAR Satellite Sentinel1A presented satisfying results to estimate and map soil moisture content.

\section{Acknowledgements}

This study was supported by Bulent Ecevit University scientific research project: 201547912266-04. The authors wish to thank to Assoc. Prof. Dr. Mustafa Tolga Esetlili for helping to carry out gravimetric soil moisture measurements. In addition, the authors wish to thank to ESA for providing Sentinel-1 data free of charge. 


\section{References}

Ahmad, A., Zhang, Y., and Nichols, S. (2011). Review and evaluation of remote sensing methods for soil-moisture estimation. SPIE Reviews, $\quad 2(1), \quad 028001$. http://doi.org/10.1117/1.3534910

Aubert, M., Baghdadi, N., Zribi, M., Douaoui, A., Loumagne, C., Baup, F., ... Garrigues, S. (2011). Analysis of TerraSAR-X data sensitivity to bare soil moisture, roughness, composition and soil crust. Remote Sensing of Environment, 115(8), 1801-1810. http://doi.org/10.1016/j.rse.2011.02.021

B. E. Myhre, and S. F. Shih. (1990). USING INFRARED THERMOMETRY TO ESTIMATE SOIL WATER CONTENT FOR A SANDY SOIL. Transactions of the ASAE, 33(5), 1479. http://doi.org/10.13031/2013.31497

Baghdadi, N., Aubert, M., and Zribi, M. (2012). Use of TerraSAR-X Data to Retrieve Soil Moisture Over Bare Soil Agricultural Fields. IEEE Geoscience and Remote Sensing Letters, 9(3), 512-516. http://doi.org/10.1109/LGRS.2011.2173155

Baghdadi, N., Camus, P., Beaugendre, N., Issa, O. M., Zribi, M., Desprats, J. F., ... Sannier, C. (2011). Estimating Surface Soil Moisture from TerraSAR-X Data over Two Small Catchments in the Sahelian Part of Western Niger. Remote Sensing, 3(6), 1266-1283. http://doi.org/10.3390/rs3061266

Balenzano, A., Satalino, G., Lovergine, F., Rinaldi, M., Iacobellis, V., Mastronardi, N., and Mattia, F. (2013). On the use of temporal series of L-and X-band SAR data for soil moisture retrieval. Capitanata plain case study. European Journal of Remote Sensing, 46(1), 721-737. http://doi.org/10.5721/EuJRS20134643

Canada Center for Remote Sensing. (1976). Fundamentals of remote sensing. Resources Policy, 2(1), 65. http://doi.org/10.1016/0301-4207(76)900659

Copernicus. (2018). Sentinel-1 — The SAR Imaging Constellation for Land and Ocean Services. Retrieved from https://directory.eoportal.org/web/eoportal/s atellite-missions/c-missions/copernicussentinel-1
Dubois, P. C., van Zyl, J., and Engman, T. (1995). Measuring soil moisture with imaging radars. IEEE Transactions on Geoscience and Remote Sensing, 33(4), 915-926. http://doi.org/10.1109/36.406677

Esetlili, M. T., and Kurucu, Y. (2016). DETERMINATION OF MAIN SOIL PROPERTIES USING SYNTHETIC APERTURE RADAR. Fresenius Environmental Bulletin, 25(1), 23-36.

Evett, S. R., and Parkin, G. W. (2005). Advances in Soil Water Content Sensing. Vadose Zone Journal, 4(4), 986. http://doi.org/10.2136/vzj2005.0099

Gao, Q., Zribi, M., Escorihuela, M., and Baghdadi, N. (2017). Synergetic Use of Sentinel-1 and Sentinel-2 Data for Soil Moisture Mapping at $100 \mathrm{~m}$ Resolution. Sensors, $\quad 17(9), \quad 1966$. http://doi.org/10.3390/s17091966

Heilman, J. ., Kanemasu, E. ., Bagley, J. ., and Rasmussen, V. . (1977). Evaluating soil moisture and yield of winter wheat in the Great Plains using Landsat data. Remote Sensing of Environment, 6(4), 315-326. http://doi.org/10.1016/0034-4257(77)900517

Jacome, A., Bernier, M., Chokmani, K., Gauthier, Y., Poulin, J., and De Sève, D. (2013). Monitoring Volumetric Surface Soil Moisture Content at the La Grande Basin Boreal Wetland by Radar Multi Polarization Data. Remote Sensing, 5(10), 4919-4941. http://doi.org/10.3390/rs5104919

Kseneman, M., Gleich, D., and Potočnik, B. (2012). Soil-moisture estimation from TerraSAR-X data using neural networks. Machine Vision and Applications, 23(5), 937-952. http://doi.org/10.1007/s00138011-0375-3

Kurucu, Y., Şanlı Balık, F., Esetlili, MT., Bolca, M. and Göksel, Ç. (2009). Contribution of SAR images to determination of surface moisture on the Menemen Plain, Turkey Int. J. Remote Sens., Vol. 30 (7) :1805-1817.

Lakshmi, V. (2013). Remote Sensing of Soil Moisture. ISRN Soil Science, 2013, 1-33. http://doi.org/10.1155/2013/424178

Lievens, H., and Verhoest, N. E. C. (2012). Spatial and temporal soil moisture estimation from RADARSAT-2 imagery over Flevoland, The Netherlands. Journal of 
Hydrology, 456-457, 44-56. http://doi.org/10.1016/j.jhydrol.2012.06.013

Moran, M. S., Alonso, L., Moreno, J. F., Cendrero Mateo, M. P., de la Cruz, D. F., and Montoro, A. (2012). A RADARSAT-2 Quad-Polarized Time Series for Monitoring Crop and Soil Conditions in Barrax, Spain. IEEE Transactions on Geoscience and Remote Sensing, 50(4), 1057-1070. http://doi.org/10.1109/TGRS.2011.2166080

Nagler, T., Rott, H., Hetzenecker, M., Wuite, J., and Potin, P. (2015). The Sentinel-1 Mission: New Opportunities for Ice Sheet Observations. Remote Sensing, 7(7), 93719389. http://doi.org/10.3390/rs70709371

Oh, Y., Sarabandi, K., and Ulaby, F. T. (1992). An empirical model and an inversion technique for radar scattering from bare soil surfaces. IEEE Transactions on Geoscience and Remote Sensing, 30(2), 370-381. http://doi.org/10.1109/36.134086

Paloscia, S., Pettinato, S., and Santi, E. (2012). Combining $\mathrm{L}$ and $\mathrm{X}$ band SAR data for estimating biomass and soil moisture of agricultural fields. European Journal of Remote Sensing, 45(1), 99-109. http://doi.org/10.5721/EuJRS20124510

Sadeghi, M., Babaeian, E., Tuller, M., and Jones, S. B. (2017). The optical trapezoid model: A novel approach to remote sensing of soil moisture applied to Sentinel-2 and Landsat-8 observations. Remote Sensing of Environment, $198, \quad 52-68$. http://doi.org/10.1016/j.rse.2017.05.041

Schmugge, T. J., Jackson, T. J., and McKim, H. L. (1980). Survey of methods for soil moisture determination. Water Resources Research, 16(6), 961-979. http://doi.org/10.1029/WR016i006p00961

Şeker, D.Z., Direk, Ş., Musaoğlu, N. and Gazioğlu, C. (2013). Determination of Effects of Coastal Deformation Caused by Waves and Storms at Black Sea Coast of Turkey utilizing InSAR Technique, American Geophysical Union, Fall Meeting Abstracts, 1629p.

Şekertekin, A. (2018). Aktif Mikrodalga Uydu Görüntü Verileri Kullanılarak Toprak Neminin Belirlenmesi. PhD Thesis. Bülent Ecevit Üniversitesi, Zonguldak, Turkey.

Sekertekin, A., Marangoz, A. M., Abdikan, S., and Esetlili, M. T. (2016). PRELIMINARY RESULTS OF ESTIMATING SOIL
MOISTURE OVER BARE SOIL USING FULL-POLARIMETRIC ALOS-2 DATA. ISPRS - International Archives of the Photogrammetry, Remote Sensing and Spatial Information Sciences, XLII-2/W1, 173-176. http://doi.org/10.5194/isprsarchives-XLII-2-W1-173-2016

Shih, S. F., and Jordan, J. D. (1992). LANDSAT MID-INFRARED DATA AND GIS IN REGIONAL SURFACE SOILMOISTURE ASSESSMENT. Journal of the American Water Resources Association, 28(4), 713-719. http://doi.org/10.1111/j.1752-

1688.1992.tb01493.x

Srivastava, H. S., Patel, P., Sharma, Y., and Navalgund, R. R. (2009). Large-Area Soil Moisture Estimation Using Multi-IncidenceAngle RADARSAT-1 SAR Data. IEEE Transactions on Geoscience and Remote Sensing, 47(8), 2528-2535. http://doi.org/10.1109/TGRS.2009.2018448

Şanlı, F., Abdikna, S., Esetlili, M. and Sunar, F. (2016). Evaluation of image fusion methods using PALSAR, RADARSAT-1 and SPOT images for land use/land cover classification. Journal of Indian Society of Remote Sensing, 45(4), 591-601.

Ulaby, F. T., Moore, R. K., and Fung, A. K. (1986). Microwave remote sensing: Active and passive; from theory to applications (Vol. Volume III, pp. 1065-2162).

Verhoest, N., Lievens, H., Wagner, W., Álvarez-Mozos, J., Moran, M., and Mattia, F. (2008). On the Soil Roughness Parameterization Problem in Soil Moisture Retrieval of Bare Surfaces from Synthetic Aperture Radar. Sensors, 8(7), 4213-4248. http://doi.org/10.3390/s8074213

Weimann, A., Von Schonermark, M., Schumann, A., Jorn, P., and Gunther, R. (1998). Soil moisture estimation with ERS-1 SAR data in the East-German loess soil area. International Journal of Remote Sensing, 19(2), 237-243. http://doi.org/10.1080/014311698216224

Zribi, M., Baghdadi, N., Holah, N., and Fafin, O. (2005). New methodology for soil surface moisture estimation and its application to ENVISAT-ASAR multiincidence data inversion. Remote Sensing of Environment, 96(3-4), 485-496. http://doi.org/10.1016/j.rse.2005.04.005 
Zribi, M., and Dechambre, M. (2003). A new empirical model to retrieve soil moisture and roughness from C-band radar data. Remote Sensing of Environment, 84(1), 4252. http://doi.org/10.1016/S00344257(02)00069-X

Zribi, M., Kotti, F., Lili-Chabaane, Z., Baghdadi, N., Ben Issa, N., Amri, R., ... Chehbouni, A. (2012). Soil Texture Estimation Over a Semiarid Area Using TerraSAR-X Radar Data. IEEE Geoscience and Remote Sensing Letters, 9(3), 353-357. http://doi.org/10.1109/LGRS.2011.2168379 Zribi, M., Saux Picart, S., André, C., Descroix, L., Ottlé, C., and Kallel, A. (2007). Soil moisture mapping based on ASAR/ENVISAT radar data over a Sahelian region. International Journal of Remote Sensing, 28(16), 3547-3565. http://doi.org/10.1080/01431160601009680 